\title{
Mobile Banking Use and Consumer Readiness to Benefit from Faster Payments
}

\author{
By Fumiko Hayashi and Ying Lei Toh
}

The U.S. payments industry is currently implementing faster payments that will enable consumers and businesses to send

1 and receive payments almost instantly at any time of day, any day of the year. Interfaces that allow consumers to access faster payments will include new or updated mobile and online banking services as well as mobile wallet or payment applications (apps) offered by nonbank payment service providers. Mobile banking in particular may allow consumers to realize the full benefits of faster payments. Compared with other interfaces, mobile banking enables consumers to make faster payments across the greatest variety of uses, from bill payments to person-to-person transfers to in-person and online purchases. The unique alert feature of mobile banking also enables consumers to be notified of an incoming payment almost instantly, wherever they are.

Because of mobile banking's advantages in accessing faster payments, consumers who already use mobile banking for transactions are likely to adopt faster payments more easily and quickly and use faster payments for a wider variety of uses than other consumers, especially in the near term. In contrast, consumers who lack the technologies to use mobile and online banking, such as a smartphone and home internet access, are less likely to benefit from faster payments. As a result, a

Fumiko Hayashi is a research and policy advisor at the Federal Reserve Bank of Kansas City. Ying Lei Toh is an economist at the bank. This article is on the bank's website at www.KansasCityFed.org 
consumer's use of mobile banking is a good indicator of their readiness to fully realize the benefits of faster payments.

In this article, we examine which consumer characteristics are associated with mobile banking use, a proxy for readiness to fully benefit from faster payments, as well as what other factors may influence consumer readiness. We find that banked households that are younger, higher income, college-educated, employed, or that occasionally use alternative financial services are significantly more likely to have used mobile banking for transactions, implying they are the most ready to fully benefit from faster payments. In contrast, banked households that are lower income, less educated, older, not in the labor force, disabled, unmarried, or in a rural area are significantly more likely to lack a smartphone and home internet access, implying they are the least ready to realize the benefits. We identify three additional factors that may influence consumer readiness: the availability and cost of digital infrastructure such as high-speed broadband internet and mobile wireless services, the availability of mobile banking and its transaction functions, and consumers' perceptions of and savviness with mobile banking and related technologies.

Section I discusses why mobile banking may enable banked consumers to more fully realize the benefits of faster payments than other interfaces. Section II considers the spectrum of consumers who may fully benefit from faster payments and examines which consumer characteristics are associated with those who are the most ready versus those who are the least ready. Section III discusses other factors that may influence consumers' readiness to benefit from faster payments.

\section{Mobile Banking and Access to Faster Payments}

In the United States, the implementation of faster payments is still at an early stage. In November 2017, the Clearing House launched the Real Time Payment (RTP) network, which provides real-time payment and settlement service to banks; as of January 2020, 21 large banks were in the network (Murphy 2020). The Federal Reserve is currently developing a similar service called FedNow, which is expected to be available in 2023 or 2024. The RTP network and FedNow are intended to connect more than 10,000 banks across the country, enabling those banks to provide faster payments to their customers for a wide variety 
of uses. In addition, as of February 2020, more than 700 banks had joined Zelle, a network that uses payment card and automated clearinghouse infrastructures to offer instant person-to-person transfers via a mobile app. ${ }^{1}$

The vast majority of banks have yet to offer faster payment services to their customers, making it hard to identify the consumers who will be the most likely to adopt and benefit from these services. One potential way to identify these consumers is through their means of access. Banks will likely provide faster payments services through various means, including mobile banking, online banking, ATMs, and physical bank branches. Of these, mobile banking may enable consumers to most fully realize the benefits of faster payments.

Mobile banking has three distinct advantages over its alternatives as a way to access faster payments. First, mobile banking allows consumers to access faster payments anytime, anywhere, while other means limit access to particular times and locations. When a consumer makes a faster payment at a bank branch or an ATM inside a retail store, for example, the consumer needs to be present during its operating hours. Although online banking does not limit access to specific times of day, it may limit access to faster payments to locations with personal computers, which are less portable and may have limited connectivity, especially when consumers are not at home or at work. Consumers may be able to access online banking through the browser of a mobile device, but doing so is likely less convenient than using an interface designed for mobile use. As a result, ATM, bank branch, and online banking may not allow consumers to fully realize a key feature of faster payments-24/7/365 availability.

Second, mobile banking may allow consumers to make faster payments for a wider variety of uses than other means. Mobile banking will likely be able to support person-to-person transfers, bill payments, online and in-person purchases, and payments for services such as ridesharing and public transit. In contrast, other means of access may only support a few of these uses. At ATMs and branches, consumers may be able to make faster payments only for person-to-person transfers and bill payments. Through online banking, consumers may be able to make faster payments for person-to-person transfers, bill payments, and online purchases, but not for in-person purchases, kiosk or vending machine transactions, and ride-sharing. 
Third, mobile banking may give consumers more control and flexibility over the timing of payments. For example, mobile banking has an alert function, allowing consumers to make time-sensitive bill payments as soon as they are notified of an incoming payment. Online banking gives consumers similar control but is less flexible than mobile banking, especially when consumers are not at home or work as discussed previously. Mobile banking's greater flexibility and control over the timing of payments may reduce the incidence of cash flow shortfalls arising from misalignments between the time incoming funds are received and the time spending needs to occur. Therefore, accessing faster payments through mobile banking may be particularly beneficial for cash-strapped consumers.

Mobile banking may also have advantages over mobile wallet or payment apps offered by nonbank payment service providers. Preexisting mobile payment apps typically limit their use. ${ }^{2}$ For example, Venmo and Square Cash focus on person-to-person transfers, while Apple Pay and Samsung Pay focus on in-person and remote purchases. ${ }^{3}$ As a result, consumers may need to use multiple apps to fulfill their faster payment needs. Moreover, some mobile payment apps require consumers to prefund the mobile payment account, complicating cash management for consumers. In contrast, mobile banking allows consumers to make faster payments for a variety of uses from a single app and keep their funds in a single account.

International experiences underscore the importance of mobile banking in accessing faster payments. In countries that have implemented faster payments more recently, such as Australia, Hong Kong, and Singapore, many banks provide both mobile banking and online banking as means to access faster payments. When the United Kingdom implemented its faster payments system in 2008, banks typically offered faster payments through online banking but not through mobile banking. At that time, consumers had not widely adopted smartphones, which were introduced in 2007. Since then, consumers have increasingly adopted smartphones, and their demand for mobile banking to access faster payments has increased. To meet this demand, UK banks now offer faster payments through mobile banking.

These countries have also broadened the uses of faster payments made through mobile devices. For example, in the United Kingdom, a few banks have recently started offering a new function of mobile 
banking called "Pay by Bank app" that enables consumers to make faster payments for remote purchases. In Australia, NPP Australia, a company responsible for maintaining and developing the New Payments Platform (NPP), has released a standardized quick response (QR) code specification for the NPP to support real-time payments via a QR code for point-of-sale, online, and bill payments. Hong Kong and Singapore also use a common $\mathrm{QR}$ code for both faster payments and other mobile payments at the point of sale. To make faster payments through mobile banking at the point of sale, consumers open their mobile banking app, scan the merchant's QR code, and enter the payment amount to instruct their bank to send the funds to the merchant's bank (Bradford, Hayashi, and Toh 2019). In these countries, technological innovation has further enhanced the benefits of using mobile banking to access faster payments relative to other methods.

\section{Consumer Readiness to Fully Benefit from Faster Payments}

Given mobile banking's advantages in accessing faster payments, consumers who already use mobile banking are most likely to fully benefit from faster payments when they are implemented. As a result, we treat mobile banking usage as a proxy for readiness to benefit from faster payments in our subsequent analysis. However, consumers are not simply "ready" or "not ready" for faster payments—instead, consumer readiness likely falls on a spectrum.

Consumers who already use mobile banking for transactions may be the most willing and able to use mobile banking for faster payments. Consumers who use mobile banking only for non-transaction activities, such as to check their account balances or receive alerts, may be slightly less likely to use mobile banking for faster payments. To the extent these consumers do not use mobile banking for transactions due to security concerns, they may not be willing to use mobile banking for faster payments, either.

Consumers who have used online banking but not mobile banking are the next most ready to benefit. These consumers are likely to be ready to access faster payments through online banking. However, they may not benefit as fully as those who use mobile banking, due to the limitations of online banking discussed previously. 
Slightly further down the readiness spectrum are consumers who have not yet used mobile or online banking services but nevertheless have the technologies to do so. These consumers would need to adopt mobile or online banking to realize a key benefit of faster payments - 24/7/365 availability — and are thus less ready to benefit from faster payments than current users of mobile and online banking. However, because these consumers already have the technologies necessary to use mobile or online banking (specifically, smartphones or home internet access), they are more ready to benefit than consumers who lack these technologies.

Consumers who lack smartphones or home internet access are likely the least ready to benefit from faster payments. Although these consumers could make outgoing faster payments at ATMs and bank branches, they could not access faster payments on a 24/7/365 basis and could not make faster payments for various uses such as in-person and online purchases. Because these consumers would need to take at least two steps to benefit from faster payments-acquire technologies and adopt mobile or online banking - they are at the bottom of the spectrum of consumer readiness.

To understand consumer readiness in greater detail, we next examine which consumer characteristics are associated with the readiness to benefit from faster payments. We use a weighted sample of 30,440 banked households from the 2017 FDIC National Survey of Unbanked and Underbanked Households. ${ }^{4}$ The FDIC survey includes detailed information on these households' sociodemographic characteristics, banking status, technology adoption, means to access a bank account, and mobile banking activities. ${ }^{5}$

Based on each household's mobile banking activities and technology adoption, we divide households into three groups in terms of their readiness to fully benefit from faster payments: the "most ready," "least ready," and "in-between." The most ready households are those who have used mobile banking for transactions. We place households in this group if they have conducted at least one of the following mobile banking transactions in the 12 months prior to the survey: bill payments, person-to-person transfers, transfers between accounts owned by the same households, and remote check deposits. About 35 percent of banked households in our sample fall into this group. We place 
households in the least ready group if they have neither a smartphone nor internet access at home. About 12 percent of banked households in our sample are in this group. The remaining 53 percent of banked households in our sample are in the in-between group. This group includes households who have used mobile banking only for non-transaction activities ( 4.5 percent), households who have used online banking but not mobile banking (26.3 percent), and households who have the technologies to use mobile banking or online banking but have used neither (22.6 percent).

The readiness to benefit from faster payments is likely to vary by household characteristic. Previous research has found adoption of new technology like mobile technology generally starts with younger, higherincome, and more-educated consumers (Gulamhuseinwala, Bull, and Lewis 2015; Lee, Lee, and Eastwood 2003). In addition, several studies have documented gaps in access to technology between rural and urban households and between low- and high-income households (Anderson 2018; Anderson and Kumar 2019). As a result, we examine the relationship between household readiness and 11 characteristics that may influence households' ability or willingness to use mobile banking, including age, income, education, employment status, and location.

Table 1 reports summary statistics for the weighted sample of banked households, including the share of households with each characteristic and the shares of the most ready, in-between, and least ready households with that characteristic. For example, banked households are assigned one of three banking status characteristics: fully banked, lightly underbanked, or heavily underbanked. Fully banked households are those that did not use alternative financial services (AFS) such as nonbank money orders, check-cashing services, payday loans, auto title loans, and pawnshop loans in the 12 months prior to the survey. In contrast, both lightly and heavily underbanked households used AFS, though the intensity of their use differed. Heavily underbanked households used AFS to pay bills and receive income in a typical month, while lightly underbanked households did not use AFS in a typical month. About 80 percent of households in our sample are fully banked, and the remaining 20 percent are almost evenly split between lightly underbanked and heavily underbanked. The last three columns of Table 1 show that 33.4 percent of fully banked households are in the most 


\section{Table 1}

Summary Statistics for Banked Household Characteristics

\begin{tabular}{|c|c|c|c|c|c|}
\hline \multirow[b]{2}{*}{ Category } & \multirow[b]{2}{*}{ Characteristic } & \multirow[b]{2}{*}{$\begin{array}{l}\text { Share of } \\
\text { sample }\end{array}$} & \multicolumn{3}{|c|}{ Share of households based on readiness } \\
\hline & & & $\begin{array}{c}\text { Most ready } \\
\text { (percent) }\end{array}$ & $\begin{array}{l}\text { In-between } \\
\text { (percent) }\end{array}$ & $\begin{array}{l}\text { Least ready } \\
\text { (percent) }\end{array}$ \\
\hline All & & 100.0 & 34.8 & 53.4 & 11.8 \\
\hline \multirow[t]{3}{*}{ Banking status } & Fully banked & 79.9 & 33.4 & 53.9 & 12.7 \\
\hline & Lightly underbanked & 9.8 & 44.9 & 49.2 & 5.9 \\
\hline & Heavily underbanked & 10.4 & 36.4 & 53.4 & 10.2 \\
\hline \multirow[t]{3}{*}{ Income } & Below $\$ 30,000$ & 23.6 & 18.1 & 54.5 & 27.4 \\
\hline & $\$ 30,000$ to $\$ 74,999$ & 39.6 & 32.4 & 57.7 & 9.9 \\
\hline & $\$ 75,000$ and above & 36.7 & 48.1 & 48.2 & 3.7 \\
\hline \multirow[t]{3}{*}{ Education } & $\begin{array}{l}\text { High school diploma } \\
\text { or less }\end{array}$ & 32.4 & 21.6 & 56.0 & 22.4 \\
\hline & Some college & 29.4 & 35.1 & 55.9 & 9.0 \\
\hline & College degree & 38.2 & 45.7 & 49.5 & 4.8 \\
\hline \multirow[t]{3}{*}{ Age } & 34 or younger & 20.9 & 58.4 & 38.4 & 3.2 \\
\hline & 35 to 54 & 34.1 & 44.4 & 50.2 & 5.4 \\
\hline & 55 or older & 44.9 & 16.5 & 62.9 & 20.6 \\
\hline \multirow[t]{4}{*}{ Race } & Black & 12.1 & 34.7 & 51.7 & 13.6 \\
\hline & Hispanic & 11.4 & 37.7 & 50.5 & 11.8 \\
\hline & White & 69.8 & 33.7 & 54.7 & 11.6 \\
\hline & Asian or other & 6.7 & 40.9 & 49.4 & 9.7 \\
\hline \multirow[t]{3}{*}{ Employment status } & Employed & 63.0 & 44.9 & 50.1 & 5.0 \\
\hline & Unemployed & 2.2 & 40.3 & 51.4 & 8.3 \\
\hline & $\begin{array}{l}\text { Not in labor force } \\
\text { or unknown }\end{array}$ & 34.8 & 16.1 & 59.6 & 24.3 \\
\hline \multirow[t]{2}{*}{ Homeownership } & Homeowner & 67.1 & 32.5 & 56.1 & 11.4 \\
\hline & Non-homeowner & 32.9 & 39.5 & 48.0 & 12.5 \\
\hline \multirow[t]{2}{*}{ Disability status } & $\begin{array}{l}\text { Not disabled or } \\
\text { not applicable }\end{array}$ & 92.4 & 35.8 & 53.1 & 11.2 \\
\hline & Disabled, age $25-64$ & 7.6 & 23.0 & 59.1 & 17.9 \\
\hline
\end{tabular}


Table 1 (continued)

\begin{tabular}{|c|c|c|c|c|c|}
\hline \multirow[b]{2}{*}{ Category } & \multirow[b]{2}{*}{ Characteristic } & \multirow[b]{2}{*}{$\begin{array}{l}\text { Share of } \\
\text { sample }\end{array}$} & \multicolumn{3}{|c|}{ Share of households based on readiness } \\
\hline & & & $\begin{array}{l}\text { Most ready } \\
\text { (percent) }\end{array}$ & $\begin{array}{c}\text { In-between } \\
\text { (percent) }\end{array}$ & $\begin{array}{c}\text { Least ready } \\
\text { (percent) }\end{array}$ \\
\hline \multirow[t]{2}{*}{ Marital status } & Not married & 50.3 & 31.5 & 52.5 & 16.0 \\
\hline & Married & 49.7 & 38.2 & 54.4 & 7.4 \\
\hline \multirow[t]{4}{*}{ Region } & Northeast & 17.5 & 32.1 & 56.2 & 11.7 \\
\hline & South & 37.7 & 33.4 & 53.9 & 12.7 \\
\hline & Midwest & 22.1 & 33.4 & 55.3 & 11.3 \\
\hline & West & 22.8 & 40.5 & 48.9 & 10.6 \\
\hline \multirow[t]{2}{*}{ Location } & Rural & 13.6 & 22.5 & 59.2 & 18.3 \\
\hline & Nonrural & 86.4 & 36.7 & 52.6 & 10.7 \\
\hline \multirow[t]{2}{*}{ Income volatility } & Not volatile or unknown & 79.1 & 32.8 & 53.6 & 13.6 \\
\hline & Volatile & 20.9 & 42.2 & 53.2 & 4.6 \\
\hline
\end{tabular}

Notes: The most ready households are those who have used mobile banking for transactions. The least ready households are those who have neither a smartphone nor internet access at home. We exclude banked households with unknown underbanked status from this analysis.

Sources: 2017 FDIC Survey and authors' calculations.

ready group, 53.9 percent are in the in-between group, and 12.7 percent are in the least ready group.

To identify which characteristics are strongly associated with readiness to benefit from faster payments, we examine whether a group of households with a given characteristic has a greater tendency to be in the most ready group. More specifically, we consider a household characteristic to have a strong, positive association with readiness if more than 43.5 percent of households with that characteristic are in the most ready group. This threshold of 43.5 percent corresponds to 125 percent of the average share of most ready households among all banked households of 34.8 percent $(34.8 \times 1.25=43.5$ percent $)$.

Using this criterion, we identify six characteristics that have strong, positive associations with the most ready households: lightly underbanked, household income at or above $\$ 75,000$, college-educated, age 34 or younger, age 35 to 54 , and employed. ${ }^{6}$ Among households with these characteristics, those age 34 or younger have by far the highest share of most ready households at 58.4 percent. Households with income at or above $\$ 75,000$ have the second highest share of most ready 
households at 48.1 percent. The other four groups - those who are lightly underbanked, college-educated, age 35 to 54, and employedhave similar shares of most ready households ranging from 44 to 46 percent. Our results suggest that about half of all households with at least one of these six characteristics are in the group most ready to fully benefit from faster payments.

We perform a similar calculation to attempt to identify characteristics that are strongly associated with in-between households. We consider a characteristic to have a strong, positive association with in-between households if the share of households with that characteristic surpasses 66.8 percent of households. This threshold again corresponds to 125 percent of the average share of in-between households among all banked households $(53.4 \times 1.25=66.8$ percent $)$. However, we find no characteristic meets or exceeds this threshold, implying none of our characteristics have a strong association with the share of in-between households.

Finally, to identify characteristics that are strongly associated with the least ready households — as defined by their lack of a smartphone and home internet access - we compare the share of the least ready households with a given characteristic to the share of the least ready households among all banked households. We consider a characteristic to have a strong, positive association with the least ready households if more than 14.7 percent of households with that characteristic are in the least ready group. This threshold again corresponds to 125 percent of the average share of the least ready households among all banked households of 11.8 percent $(11.8 \times 1.25=14.7$ percent $)$.

We find seven characteristics have strong, positive associations with the share of least ready households: income below $\$ 30,000$, less educated, age 55 or older, not in the labor force, working-age disabled, not married, and living in a rural area. Among households with these characteristics, those with incomes below $\$ 30,000$ have the highest share of least ready households at 27.4 percent, followed by those that are not in the labor force at 24.3 percent. Households that have a high school education or less have the third highest share of least ready households at 22.4 percent, while households with householders age 55 or older have the fourth highest share at 20.6 percent. Households that live in a rural area, are working-age disabled, and are unmarried have shares ranging from 16.0 to 18.3 percent. Our results suggest that, among households 
with one or more of these seven characteristics, at least one in six have neither a smartphone nor internet access at home and are, therefore, least ready to fully benefit from faster payments.

\section{Factors that Influence Consumer Readiness}

Consumer readiness to fully benefit from faster payments significantly varies by consumer characteristic. Households that are younger, higher income, college-educated, employed, or lightly underbanked are more likely to be in the most ready group, while households that are lower income, less educated, older, not in the labor force, disabled, unmarried, or in rural areas are more likely to be in the least ready group. Based on these characteristics, we identify three possible factors that influence consumer readiness.

The first possible factor influencing consumer readiness is the availability and cost of technologies needed to access mobile banking or online banking: namely, a smartphone and mobile broadband or wireless broadband internet access. In particular, the digital divide between rural and nonrural areas may help explain our finding that rural households are more likely to lack technologies for mobile and online banking. A Pew Research Center survey found that 24 percent of consumers in rural areas perceived a lack of high-speed internet access to be a major problem in their areas, more than double the shares of consumers in urban and suburban areas (Anderson 2018). A report from the Federal Communications Commission (FCC) also noted a substantial gap in deployment rates of high-speed fixed and mobile broadband between urban and rural areas (FCC 2019). In urban areas, the deployment rates of high-speed fixed and mobile broadband in 2017 were 98 percent and 93 percent, respectively, while in rural areas, these rates were 74 percent and 69 percent. Moreover, consumers in rural areas tend to have fewer providers to choose from. According to another FCC report, 30 percent of rural consumers lived in areas covered by three or fewer mobile wireless networks in 2016, while more than 98 percent of urban consumers lived in areas covered by four or more wireless networks (FCC 2017). Limited competition among networks in rural areas may result in higher costs of services for rural consumers and, consequently, lower adoption of broadband services. 
Even when broadband services are available, some consumers may not be able to afford them. The high costs of broadband services as well as smartphones may render these technologies unaffordable for many lowincome households. Indeed, our analysis in the previous section shows that households with lower income or that are not in the labor force are much less likely to have a smartphone and home broadband access.

The second possible factor influencing consumer readiness to fully benefit from faster payments is the availability of mobile banking services at consumers' banks. Even if consumers have a smartphone and internet access, they will not be able to use mobile banking for transactions unless their banks offer this service. Data from the 2016 Mobile Financial Services Survey of Financial Institutions (mobile FS survey) show that small community banks are less likely to offer (or plan to offer) mobile banking services than their larger counterparts and credit unions. ${ }^{7}$ Specifically, only about 85 percent of community banks with total assets below $\$ 100$ million either offered mobile banking in 2016 or planned to do so within the next two years. In contrast, almost all larger banks with total assets above $\$ 100$ million and 92 percent of credit unions with total assets below $\$ 100$ million did or planned to do the same. In addition, we find small community banks are less likely than larger banks to offer mobile transaction functions. For example, only 68 percent of small community banks offered (or planned to offer) mobile bill payments in 2016, and only 46 percent offered (or planned to offer) mobile person-to-person transfers. In contrast, 97 percent and 82 percent of larger banks, respectively, offered (or planned to offer) mobile bill payments and mobile person-to-person transfers.

Together, these findings from the mobile FS survey suggest that consumers who bank with small community banks may be less likely to use mobile banking for transactions. These consumers may also be lower income, as small community banks offer services that are more attractive to lower-income customers. For example, small community banks offer checking accounts that are less expensive for consumers with low account balances. According to Moebs Service (2019), community banks with total assets below $\$ 100$ million were more likely than other types of banks to offer checking accounts with no monthly account fee and a low overdraft fee. Our finding in the previous section of lower-income households' tendency not to use mobile banking for 
transactions may, therefore, be at least partly explained by the tendency of small community banks not to offer mobile banking.

The third possible factor influencing consumer readiness to fully benefit from faster payments is consumers' perception of and familiarity with mobile banking and related technologies. Consumers who have positive perceptions of mobile banking and know how to use it may be more willing to use mobile banking to access faster payments than those who have negative perceptions of mobile banking or do not know how to use it. A 2016 consumer survey on mobile financial services asked banked consumers who owned a mobile phone but did not use mobile banking why they chose not to use mobile banking (Dodini and others 2016). While the two most cited reasons are associated with the lack of perceived benefits from mobile banking, the third, fifth, and seventh most cited reasons are associated with negative perceptions of mobile banking, including security concerns (73 percent), a lack of trust in technology (40 percent), and difficulty in using mobile banking (18 percent). ${ }^{8}$ The survey also asked consumers about their confidence in their ability to understand and navigate the mobile phone technology and features. Although more than half of consumers were very confident in their ability ( 51 percent), 37 percent of consumers were somewhat confident, and 11 percent were not confident.

Using data from the 2016 consumer survey, we find consumer perception and savviness are both associated with each other and associated with some consumer characteristics. Those who are less confident in their ability to understand and navigate the mobile phone technology tend both to lack trust in the technology and find it difficult to use. These consumers tend to be older, less educated, lower income, and not in the labor force. Our finding in the previous section of lower consumer readiness to benefit from faster payments among households that are older, less educated, lower income, or not in the labor force may be partly explained by these households' low technological savvy and negative perceptions of mobile banking.

\section{Conclusion}

The U.S. payments industry is currently implementing faster payments that will enable consumers and businesses to send and receive payments almost instantly on a 24/7/365 basis. Although U.S. 
consumers may be able to access faster payments through various means, mobile banking is most likely to allow them to fully realize the benefits of faster payments. Mobile banking allows consumers not only to make faster payments for a wide variety of uses from a single app anytime, anywhere, but also gives consumers more control and flexibility over the timing of payments. Because of these features, whether consumers use mobile banking is a good indication of their readiness to fully benefit from faster payments.

We examine which consumer characteristics are associated with their readiness to realize the benefits of faster payments and what other factors may influence consumers' readiness. We find younger, higher-income, college-educated, employed, or lightly underbanked households tend to be the most ready to fully benefit from faster payments. In contrast, lower-income, less educated, older, not in the labor force, disabled, unmarried, or rural households tend to be the least ready. We identify three additional factors that may influence consumer readiness: the availability and cost of technologies needed to use mobile or online banking, the availability of mobile banking at consumers' current banks, and consumers' perception of and familiarity with mobile banking.

Our findings suggest that promoting mobile banking along with faster payments to consumers is an important step for the U.S. payment industry as it implements faster payments. Encouraging community banks to offer mobile banking, ensuring the security of mobile banking, and increasing consumers' familiarity with mobile banking and technology may also be important. Finally, narrowing the digital divide between rural and urban areas may help ensure the benefits of faster payments extend broadly to U.S. consumers. 


\section{Endnotes}

${ }^{1}$ The number of financial institutions that participate in Zelle is reported on the company's website.

${ }^{2}$ Notable exceptions are Alipay and WeChat Pay in China, which enable consumers to make a wide range of payments, including person-to-person transfers, remote and in-person transactions, bill payments, and public transit fare payments, with a single app. However, no such apps are currently available in the United States.

${ }^{3}$ Many of these apps use payment card or automated clearinghouse infrastructure.

${ }^{4}$ We exclude unbanked consumers - those who do not have a checking or savings account-from our analysis because having a bank account is a prerequisite to using mobile and online banking. Many unbanked consumers rely heavily on cash and lack a smartphone and home internet access. Providing unbanked consumers with access to faster payments presents a unique set of challenges, which are beyond the scope of this article. We also exclude households from our sample if their banking status is unknown.

${ }^{5}$ In the FDIC survey, mobile banking activities are defined as activities that use a bank's mobile website or app.

${ }^{6}$ For characteristics that vary across individuals in a household, such as education, age, race, employment status, and disability status, the reported characteristics are those of the householder, who owns or rents the home. If a home is owned or rented jointly, the householder is designated as the "reference person" to whom the relationship of any other household members is recorded.

${ }^{7}$ We are able to access the data of the mobile FS survey because the Federal Reserve Bank of Kansas City is one of the seven Federal Reserve Banks that conducted the survey. Crowe, Tavilla, and McGuire (2017) provide consolidated findings from the survey.

${ }^{8}$ The lack of perceived benefits from mobile banking services may have little influence on consumers' readiness. Because consumers may not be able to fully realize the benefits of faster payments without using mobile banking, the availability of faster payments through mobile banking will likely increase consumers' perceived benefits, and therefore adoption, of mobile banking. 


\section{References}

Anderson, Monica. 2018. "About a Quarter of Rural Americans Say Access to High-Speed Internet Is a Major Problem.” Pew Research Center, Fact Tank, September 10 .

Anderson, Monica, and Madhumitha Kumar. 2019. "Digital Divide Persists Even as Lower-Income Americans Make Gains in Tech Adoption.” Pew Research Center, Fact Tank, May 7.

Bradford, Terri, Fumiko Hayashi, and Ying Lei Toh. 2019. "Development of QR Code-Based Mobile Payments in East Asia." Federal Reserve Bank of Kansas City, Payments System Research Briefing, June 18.

Crowe, Marianne, Elisa Tavilla, and Breffni McGuire. 2017. "Mobile Banking and Payment Practices of U.S. Financial Institutions: 2016 Mobile Financial Services Survey Results from FIs in Seven Federal Reserve Districts.” Federal Reserve Bank of Boston, December.

Dodini, Sam, Alejandra Lopez-Fernandini, Ellen Merry, and Logan Thomas. 2016. "Consumers and Mobile Financial Services 2016." Board of Governors of the Federal Reserve System, March.

FCC (Federal Communications Commission). 2019. “2019 Broadband Deployment Report.” Washington, DC, May.

- 2017. "Mobile Wireless Competition Report (20th Annual)." Washington, DC, September.

Gulamhuseinwala, Imran, Thomas Bull, and Steven Lewis. 2015. "FinTech Is Gaining Traction and Young, High-Income Users Are the Early Adopters." Journal of Financial Perspectives, vol. 3, no. 3.

Lee, Eun-Ju, Jinkook Lee, and David Eastwood. 2003. "A Two-Step Estimation of Consumer Adoption of Technology-Based Service Innovations.” Journal of Consumer Affairs, vol. 37, no. 2, pp. 256-82. Available at https://doi. org/10.1111/j.1745-6606.2003.tb00453.x

Moebs Service. 2019. “Where's the Lowest Price Checking?” January 29.

Murphy, Steve. 2020. "The Clearing House Is About to Quadruple the RTP Single Transaction Limit." Payments Journal, January 24. 